\title{
Leonid Brezhnev and His Orientations Towards France
}

\author{
Dr. Tareq Najm Abdul Wahid, General Directorate of Education in Babil, Ministry of Education -Iraq, \\ aws66t88@gmail.com \\ Dr. Khalaf Obaid Hamood, General Directorate of Education in Babil , Ministry of Education -Iraq, \\ kahhak401@gmail.com \\ *Corresponding Author
}

\begin{abstract}
Brezhnev is one of the most prominent figures who ruled the Soviet Union for several decades. He managed to overcome his severe life and passed all the difficulties and obstacles that stood in his way until he was able to ascend power in his country, banishing all opponents and strengthening the pillars of his rule. Despite the economic and political problems that Brezhnev faced, he was able to rule his country with strength and sophistication. Brezhnev remained in power until 1982 despite his exposure to assassination and attempts to remove him. Brezhnev was able to establish strong relations with France, that European country with which his country intersected for a long time, but he was able, at the end, to restore the confidence of the French in his country. So, the French President visited the Soviet Union and the two sides concluded treaties and agreements that had a prominent effect in strengthening the bonds of trust and trade exchange between the two countries.
\end{abstract}

Keywords: Bergenev, Pompidou, the Soviet Union, France, relations

Received: 05.12.2020 $\quad$ Accepted: 10.01.2021 $\quad$ Published: 07.02.2021

\section{INTRODUCTION}

Leonid Brezhnev is considered one of the most prominent figures who ruled the Soviet Union for the period from 1968-1982. He managed to occupy a number of political positions for several years until he managed to take control of the Central Committee of the Soviet Communist Party. During that period, he was able to consolidate the pillars of his rule, remove his opponents and develop his country's relations with other countries, especially France. Despite the extreme caution on the part of the French in entering into relations with the Soviet Union, he succeeded in restoring the French's confidence in him. He visited France and presented an official invitation to the French President Pompidio to visit the Soviet Union. As a result of these mutual visits, the horizons of cooperation had been deepened and trade exchange reached the peak in 1975.

Studying the character of Brezhnev is of utmost importance due to its clear influence at the local level. He managed to rule the Soviet Union for a long time in a difficult circumstance, especially the Cold War between his country and the United States of America, alongside with his constant work to develop his country's relations with the European countries. In the forefront of these countries is France, which he succeeded to open the horizons of cooperation with.

This research paper starts with an overview of Brezhnev's life, upbringing, study, circumstances of his access to power, and his relations and orientations towards France while removing barriers between the two countries, and consolidating the horizon of cooperation in all areas between the two countries during Pompidou's presidency of France.

The current research falls into an introduction, two sections and a conclusion. The first section covers the birth of Brezhnev, the history of his upbringing, the circumstances surrounding him, his education, and his inclusion in political positions until he assumed the presidency of the Central Committee of the Soviet Communist Party. In the second section, the two researchers dealt with the orientations of Brezhnev towards France, the development of relations between the two countries, and the most prominent committees that were formed to deepen joint cooperation and leaders' visits to each other's countries.

The researcher relied on a number of Arabic, English and Russian references that significantly enrich the research with valuable information. At the forefront of these references is a master's thesis entitled 'Development of American-Soviet Relations during the Era of Leonid Brezhnev 1964-1982' by Ayah Maasinri and Hajira Rami. Russian books have had a prominent role in the research, most notably, CoBeTCKOфранцузсие ОТНошения, Докуиенты 1965-1976, in which the researcher touched on the Soviet-French 
relations and the discussions of Brezhnev and Pompido. The English book Ina L Navazelskis, Leonid Brezhnev, Chelsea House Publishers, has had a significant role in clarifying the life and upbringing of Brezhnev and the circumstances of his access to power.

\section{Leonid Brezhnev and his Orientations towards France}

\section{Section One}

\section{Leonid Brezhnev}

\section{Birth and Upbringing}

Leonid Brezhnev was born on December 19, 1906 in Kamenskoye, in the Yekaterinoslav Province (now Dneprodzerzhinsk), which belongs to Ukraine and is located in the south of Ukraine. He grew up in the city of his father, Ilya Yakovlevich Brezhnev, in a working-class village, from the Brenicha Yakovlev family of Brezhnev in Kursk. It is located in the western part of central Russia, $530 \mathrm{~km}$ south of Moscow. His father moved from it to Kamenskoy in 1900 due to poverty that afflicted people in search of a source of livelihood. There, he worked in a mill and his work was tiring and arduous due to the long working hours ranging from twelve to eighteen hours a day. He married Victoria Natalia Denisovna in 1904 but she soon passed away. When she gave birth to Leonid in 1906, she took great interest in him and she wanted him to be a skilled worker in an iron and steel factory in order to help his father. As for the children, they were Yakov Ilyich Brezhnev who was born in 1908 and the sister Vera Brezhnev who was older than Leonid.

Leonid Brezhnev lived in his father's single-room house with a dirty floor. His mother took care of his education. At an early age, he entered a classic school to learn writing and arithmetic to be eligible to enter high school. One of its conditions was that the applicant pass the test of reading, writing and arithmetic. Leonid was taught by a special tutor in spite of the conditions of his poor family that provided the tutor wages with arduous difficulty. In September 1915, Leonid Brezhnev applied to the high school and managed to pass the exam and was accepted at the age of nine years. His family suffered from the high tuition fees. In addition to the difficulty of the curriculum, the discipline in the school was so strict. The school uniform should be clean and tidy that missing one of the buttons would be a sufficient reason for the student to be punished. Leonid studied biology, mathematics, chemistry, physics, and world history, as well as compulsory language courses, Russian, Latin, French, and German. Brezhnev was ambitious. He studied diligently and showed excellence in the study of the aforementioned sciences and the Russian language, but he remained below average in studying foreign languages. He rarely participated in these class because of the difficulty of studying foreign languages. He also took some religious lessons in local Russian orthodoxy on special occasions such as national holidays. Religious lessons were offered to students in the school hall. Leonid Brezhnev continued his high school studies for six years and graduated in 1921. During that time, Leonid was interested in researching the causes and disasters of the Russian October Revolution of 1917 and the First World War.

After graduation, he continued to work with his father in the mill as a worker, and he was happy with his work as he began to provide assistance to his father and his family. In addition to that, Leonid Brezhnev took a look at the conditions of his country through several trips. Sometimes his trips were on foot and on horseback. He learned about the conditions of the countryside and the hard work of the farmer. He learned the profession of farming by going to his father's original home in Kursk several times. This was in addition to continuing his work. Ukraine was subjected to a civil war in which poverty prevailed and its economic conditions deteriorated due to the burning of agricultural crops and the closure of shops, accompanied by a severe drought in Ukraine. Families started suffering from distress. Leonid Brezhnev's family was forced to emigrate to Kursk, in which Leonid applied to the Agricultural College in 1923. After passing the test, he was accepted in the Land Survey Department. What supported him to continue his studies was that he obtained a scholarship, and in 1927 he graduated from the Agricultural College as a land surveyor and practiced his profession in one of the Kursk regions.

It should be mentioned that Leonid Brezhnev did not participate in the revolution or the civil war because of his young age, but he was inclined to the Bolsheviks. During his study, he got acquainted with a Russian-born student who was studying at the Kursk Medical College called Viktoriya Petrovna. He married her in 1928 and she gave birth to his daughter Galina in 1929 in the Bisertsky district 1,000 miles east of Moscow. 
Brezhnev was then appointed deputy head of the executive committee of the Bezir district in the Ural region (1929-1930) and deputy head of the regional land administration in the Urals. Then, he joined the youth organization of the Communist Party, and the party itself in 1929, and on February 13, 1930, he was appointed the head of Sverdlovsk District Land Administration. He remained at this position until 1931, then he returned to his homeland, working in the mining factory and taking the evening classes of the Mining Institute.

In September 1930, Brezhnev left the Ural and entered the Moscow Institute of Construction Machinery. In the same year, he was transferred to the evening faculty of the Dzerzhinsky Institute, and in conjunction with his studies, he worked as a mechanic at the Dneprovsky metallurgical plant. On May 5, 1935, he obtained a diploma with a qualification as an engineer for thermal energy. During this period Brezhnev was called to work in the military service of the Soviet Red Army for a period of one year, November 1935 to 1936. After the end of the military service, Leonid Brezhnev became an employee of the Communist Party and director of Technical School of Ukraine.

In the period from 1936 to 1937, Brezhnev became director of the Metallurgical Technical School in Dzerzhinsky, and at the beginning of 1937, he worked as an engineer at the Dneprovsky Metallurgical Factory. In May of the same year, he was elected deputy head of the executive committee of the same city and remained for a whole year. Then, since May 14, 1938, he worked as head of the department of the Dnepropetrovsk Regional Committee of the Communist Party of Ukraine.

During World War II (1939-1945), Brezhnev was appointed secretary of the party committee in propaganda affairs in Kamenskoy district and head of the military industries department in the same district. He also worked as a political advisor in the Soviet army led by Nikita Khrushchev, as they became political allies during that period. During the German invasion of the Soviet Union on July 22, 1941, Brezhnev, as a high-ranking official, evacuated industries from the city of Vibroprovsk to the east of the Soviet Union, then was appointed a political commissioner after the fall of the city on May 26, 1941. He then moved to the political administration of the southern front with the rank of major general-political commissioner in November of the same year, and deputy head of the political administration of the Caucasus Front, after the German occupation of Ukraine in 1942. Thus, Brezhnev spent the war as political commissar instead of military commander. By the end of the war, he helped rebuild Ukraine from his position as first secretary of the Party Committee in Zaporozhye Province. He then held the same position in Dniprovsk in 1950 where he enjoyed a good standing among party activists. At that time, he surrounded himself with people who could support him personally and enable him to assume the position of First Secretary of the Party Communist Republic of Moldova in the period from 1951-1953. He had good relations with the head of the Propaganda Department of the Communist Party of Moldova. Under this position, Brezhnev was elected as a delegate to the Nineteenth Congress of the Communist Party in Moscow, and then he was elected Secretary of the Central Committee and a member of the Presidium of the Central Committee of the Communist Party.

Brezhnev showed complete loyalty to Joseph Stalin, who helped him to reach the highest ranks of power and became at the end of his rule a member of the Central Committee of the Soviet Communist Party and a member of the party secretariat. Brezhnev as a secretary and a political party activist was not seen as a permanent member as his party colleagues were waiting for him to be excluded from the party.

After Stalin's death in March 1953, Brezhnev was discharged of the two positions, that is, of the Central Committee of the Communist Party and membership of the Presidium of the Central Committee. He was appointed head of the Political Department of the Naval Ministry. But with the unification of the ministries (military, navy, education, and defense ministry), Brezhnev was left without any position. In May 1953, he addressed a letter to the Chairman of the Council of Ministers of the Soviet Union M. Malenkov with a request to send him to work in the Party Organization in Ukraine, and his request was approved.

Brezhnev returned to the ranks of the Soviet Army by order of the Minister of Defense No. 01608 dated May 21, 1953. From May 21, 1953 to October 27, 1954 he became Deputy Head of the Main Political Department of the Soviet Army and Navy. Then he was transferred to Kazakhstan, where he worked for the second time. In 1955, Brezhnev became the first secretary of the Central Committee of the Communist Party, supervising the development of lands, and participating in the preparation for the construction of the Baikonur base in central Kazakhstan.

In October 1956, Brezhnev became the Secretary of the Central Committee of the Communist Party, and for the period from 1956-1957 he became a candidate member of the Presidency of the Central Committee of the Communist Party, as he became close to the ruling circle surrounding Khrushchev. Then, Brezhnev won the conflict that brought him to the position of Chairman of the Presidency of the Supreme 
Soviet Council, the highest official position reached by Brezhnev in 1960, and he remained in that position until July 1964.

\section{Conditions of Brezhnev's Access to Power}

In the last years of the rule of Kharshoof of the Soviet Union, he faced many internal and external economic, political and military problems. Voices began to raise to dismiss him and calls increased to remove him from the head of power in the Soviet Union. A meeting was held on October 14, 1964 during which Brezhnev proposed dismissing Kharshoof. This pushed the meeting members to take a decision to depose Kharshoof from all his party and government positions under the excuse of old age.

A collective leadership was elected on October 15, 1964, consisting of three members. Brezhnev was elected as the first secretary of the Central Committee, Alex Kosginas the head of the government, and Nikolai Podgornyas head of the Supreme Soviet. The new leadership affirmed its commitment to the unity of Soviet lands and $\mathrm{c}$ anceled the hostile speeches that were used by Kharshoof.

Soon after that, Brezhnev began to surpass his colleagues, albeit the leadership was collective. Because of his position as head of the Soviet Communist Party, which gave him the supremacy in power especially since he had the support of the Soviet military establishment, he was able to gradually get rid of his partners when he referred them to unimportant positions in the government and unions. He continued this way until he was able to fully control power in 1968.

On January 22, 1969, during the official meeting of the crews of the ships Soyuz 4 and Soyuz 5, Brezhnev was subjected to a failed assassination operation by a policeman named Victor Elaine, a junior lieutenant in the Soviet Army. Elaine chose this moment specifically for the assassination to become a global scandal. He escaped from his platoon in the suburbs of Leningrad (now Saint Petersburg) while he was on duty with two Makarov pistols, and arrived by plane to Moscow with the aim of assassinating the SecretaryGeneral whose party was carrying out a corrupt and anti-people policy, according to Elaine. He came to Red Square in the morning two hours before the arrival of the government motorcade, wearing a police uniform which he took from his uncle who was serving in the Moscow police at that time. The Secretary-General Brezhnev was supposed to be killed in the accident. There were astronauts accompanying Brezhnev, those were Leonov, Nikolaev, Trishkova, and Prijovoy. Elaine fired 16 shots at the first two cars from the government motorcade, but the attempt failed because Brezhnev was taking the third car. In the accident, Zharkov, the driver of one of the cars, was killed, while an astronaut and a guard were injured. The committer was arrested immediately, and the head of the Soviet security services, Yuri Andropov, personally interrogated him. Perhaps the most surprising thing about this story was that Elaine was not sentenced to death and was instead sent to the madhouse. Many doubted that he was mentally ill0.

In November 1972, Brezhnev had a stroke, yet Academic Chazov treated him before the visit of Prince Philip from the Union of Soviet Socialist Republics (henceforth USSR). In 1973, the Ministry of Foreign Affairs provided him with a brief description of the people he would meet 0 .

Leonid Brezhnev was described as "a strong-willed person, radiating confidence and competence, while not possessing remarkable intelligence. He loves hunting, football and driving. He does not speak English0". Brezhnev continued his ceaseless activity in order to confine positions to his own hands. In May 1976, he obtained the rank of Marshal of the Soviet Union, which is the highest military rank, and in 1977 he issued a new constitution named after him, explaining that Soviet society entered the stage of communist construction0. In the same year, he became Chairman of the Council of the Supreme Soviet, in addition to his previous positions, he became the head of both the party and the state in the Union of Soviet Republics. Brezhnev continued to exercise his powers, whether within the party, the state or the army until his death on November 10, 19820.

\section{Section Two}

\section{Brezhnev Orientations towards France 1969-1974}

During the presidency of Georges Pompidou0 of France (1969-1974), several documents were signed between the Soviet Union and France that raised bilateral relations to a higher level. In general, during the years when Pompidou was President of the Republic, Franco-Soviet relations developed greatly in all fields. Suffice it to say that during that period five summits were held during the visits of the French President to the USSR and Leonid Brezhnev's visit to France and two basic agreements were signed. That period represented a new step in the development of relations between the two countries. 
The idea of a Franco-Soviet agreement on the political orientation of both countries first appeared in 1964. The initiative came from the Soviet side, according to French diplomats. The first idea of signing a serious political agreement was expressed by the Soviet Prime Minister Kosgin in a meeting with the French diplomat (F. Bodi) in September 1964. It was about giving the French-Soviet relations a contractual nature which was encouraged by Brezhnev.

In November 1965, the two partners spoke with the French Prime Minister M. Cove de Morville on the possibility of developing political cooperation between the two countries. After signing Charles de Gaulle's visit to the USSR in 1966, the Soviet-French declaration continued, and the topic of the "new step" in bilateral relations continued to develop and was repeatedly negotiated between diplomats in both countries 0 . In the fall of 1966, Brezhnev visited France. He chose France to appear on the international scene, and it was the first diplomatic step towards the West, and most observers in Moscow described Brezhnev as the founder of Soviet diplomacy.

With the approach of Pompidou's visit to the Soviet Union scheduled to start on October 6, 1970, the idea of the so-called "new step" was raised, but the situation was slightly complicated by the unwillingness of any of the partners to present an official proposal, that is, to take the initiative of signing a political document. The position of the Soviet delegation was based on the fact that if the French side is interested in developing political cooperation, it should give a signal, and then relations will advance forward. However, there were no indications, and a month before the visit of the French President, there was no clarity on the issue of signing the document and agreements for cooperation between the two sides.

With the encouragement of Brezhnev, the co-chair of the interstate bilateral committees for cooperation in the field of science, technology, trade and economy between the USSR and a number of Western European countries, D. M. Gevishani, declared on September 17 and 23, 1970 the interest of the USSR in signing the Treaty of Friendship and Cooperation with France, with reference to the relationship between political treaty and development of bilateral economic relations in which France was interested.

A meeting was held between the Soviets and the French on September 29, 1970, when the SecretaryGeneral of the French Ministry of Foreign Affairs Elvan held consultations with the Ambassador of the Soviet Union to France, V. E. Zoran. Also, on September 30, he held another meeting with a member of the Council of the Ministry of Foreign Affairs of the Soviet Union Kovalev in which he explained their position towards the Soviet Union. The Soviets diplomats considered this a long-awaited signal. On October 1, 1970, the Soviet Minister of Foreign Affairs Gromyko spoke of concluding a bilateral agreement that should deepen cooperation and regular political consultations as a serious step in developing Franco-Soviet relations. On October 3, 1970, Kovalev delivered the Soviet version of the political consultations agreement. Despite the French disagreement on a number of provisions of the proposed document, the two parties decided to take it as a basis for further negotiations. On October 7, during Pompidou's visit to the Soviet Union and his meeting with Brezhnev, negotiations entered an active phase on the Soviet side.

We note that until the last moment, there were violent conflicts raging within the French leadership over the need to sign an agreement on political cooperation with the Soviet Union. Most of the administration of the French Foreign Ministry, especially diplomats J. B. Raymond and C. Arnaud, opposed signing a risky agreement, from their point of view. On the contrary, diplomats Alfan and Sidow accepted this idea enthusiastically and believed that signing the agreement was necessary for the development of bilateral cooperation. The French Foreign Minister M. Skoman and the Secretary General of the Office of the President of the Republic M. Joubert took a medial position in general. They considered it useful to re-emphasize the traditional friendship with the Soviet Union, while not restricting France in its foreign policy activities.

Pompidou doubted it for a long time before making a decision, nevertheless the Soviet-French Protocol was signed on October 13,1970 as a result of lengthy consultations between him and Brezhnev. The decision of the French President is due to a number of objective reasons. Signing an agreement on political cooperation with the Soviet Union is the main goal of French diplomacy. The protocol signed by Pompidou and Gromyko after his visit to the Soviet Union stated the following:

The Presidency of the Supreme Council of the USSR and the President of the French Republic reaffirms the provisions and spirit of the Declaration of 30 July 1960, signed by the President of the Supreme Council of the USSR and the President of the French Republic during General Charles de Gaulle's visit to the Soviet Union. The reason for this is the desire of the administration to contribute to maintaining peace in all parts of the world, to recognize of the responsibility that lies in this regard with the Soviet Union and France as permanent members of the United Nations Security Council, to fulfill of the responsibility that both countries bear in Europe as a result of the Second World War, and to pursue, in accordance with the existing 
traditional friendship between the two countries and the two peoples, maintaining the special ties established between them in 1966 in the fields of economy, science, technology and culture, and their determination to give new impetus to their political cooperation. They agreed on the following:

First: In case of actions that pose a threat to peace, violate it, or cause international tensions, the governments of the Soviet Union and France will immediately communicate with each other in order to coordinate their positions on all aspects of such cases and the measures that allow dealing with them.

Second: The Soviet Union and France shall expand and deepen political consultations on important international problems of common interest. These consultations will cover the following:

- Developing the situation in Europe, strengthening reconciliation and cooperation, and strengthening security on the continent.

- Considering all cases in which international security is endangered.

- Conducting talks regarding the problems of common interest that are subject to multilateral international negotiations, including those being discussed at the United Nations and any other issues that the two parties see as useful.

Third: The provisions mentioned above do not affect in any way the obligations that the signatory parties undertook earlier in relation to other countries and they are not directed against any of them.

Fourth: Conducting political consultations regularly by the foreign ministers or representatives specially appointed for these purposes whenever necessary and, in principle, twice a year.

Pompidou played an important role in concluding the protocol as a result of the rapprochement between the Soviet Union and the Federal Republic of Germany. The German factor as a whole was crucial to the French president's diplomacy because Pompidou was so concerned about the growing economic power of Germany and the "Eastern Policy" of the new West German chancellor Willie Brandt. Just two months before Pompidou's visit to the Soviet Union on August 12 ${ }^{\text {th }}, 1970$, an agreement was signed between the Soviet Union and France, which represented a change in the international situation for France. Bonn's independent external measures threaten to lose France's leadership role in defusing future tensions and leadership within a united Europe. The signing of the protocol, in general, was supposed to contribute to the continuation of the line towards European secession, in the inclusion of Brandt's "East Policy" in the wider international process with many players. Only in this case could France control the actions of its eastern neighbor, as well as geopolitical reasons, did the signing of the document with the Soviet Union open new economic opportunities for France. The fact is that the conclusion of profitable economic contracts depends on the level of development of bilateral political relations. De Gaulle's successful visit to the USSR and the 1966 Declaration signed in 1966 led to a marked increase in trade between the USSR and France.

During Pompidou's visit to the Soviet Union, the topic of developing economic cooperation was frequently raised and much attention was paid. The parties noted with satisfaction the continuous and reciprocal development of trade relations, and the two sides expressed their hope that more success will be achieved in the future.

On November $30^{\text {th }}, 1971$, during Leonid Brezhnev's official visit to France, two important SovietFrench agreements related to the principles of cooperation between the Soviet Union and France and the upcoming Soviet-French declaration were signed. This was the first visit by the Soviet leader to a Western country, and he called it to be the main event of the Soviet foreign policy.

In a telegram dated November $29^{\text {th }}, 1971$, a Soviet Foreign Ministry official named Alfan wrote that shortly before the start of the visit, the Soviet side made it clear that it was in the interest of the two parties to sign an agreement or conclude an agreement that would raise bilateral relations to a higher level. As for the French, who refused to continue the path towards developing relations with the Soviet Union, they agreed to sign a document defining the principles of cooperation between the two countries. That document would complement the protocol announced in 1971, which would increase ties between the two countries and strengthen their relations.

The Soviet-French negotiations in 1971 took place between the General Secretary of the Central Committee of the Communist Party, a member of the Presidium of the Supreme Soviet of the USSR Brezhnev and French President Pompidou during Brezhnev's visit to France. Those negotiations confirmed the principles of cooperation between the USSR and France. The preamble of this document also affirmed the common desire of the Soviet Union and France to enhance the contribution of both countries to the cause of peace in Europe and all over the world and to promote the development of cooperation between all countries.

These principles, which reflect the desire of the Soviet Union and France to cooperate, had been exclusively identified in the service of peaceful goals. This cooperation is based on reciprocal treatment of the 
benefits and obligations of each of the two countries, and neither targets the interests of any people, nor affects, in any way, the obligations that both countries assume. It is considered one of the important elements of the Soviet-French relations in the commitment of both parties to the policy of harmony. Cooperation between the Soviet Union and France will continue to follow, as it is called to become a fixed policy in their relations and a constant factor in international life. Political cooperation between the Soviet Union and France aimed to contribute to the restoration of peace in conflict areas, the weakening of international tension, and the settlement of disputed issues by peaceful means.

In addition, the document signed between the two parties affirmed the responsibility of the USSR and France in regard to the development of world events, which the countries bear as permanent members of the United Nations Security Council. In cases that threaten or violate peace or cause international tension, the USSR and France will operate in accordance with the Soviet-French Protocol of October 13, 1970.

The Soviet Union and France reaffirmed the importance of their efforts to ensure an early political settlement in regions where the world is under threat or abuse. Both countries will contribute to solving the problem of general and complete disarmament, and above all, nuclear weapons, to overcome the division of the world into military and political groups, and to strengthen the role of the United Nations in accordance with the provisions of its Charter.

The provisions of Article 11 to 13 are devoted to bilateral relations between the Soviet Union and France, the development of economic and trade exchange, scientific and technical cooperation, and cultural relations. In these items, the document emphasized the importance of their bilateral relations in all areas that would be built so that they would be a good example of equal cooperation between countries of different social structure. Consequently, this document contains the agreed principles and provisions that guide both countries in their actions on the international scene, especially in Europe. These principles form the basis of their political cooperation. This agreement was the first of its kind in the relations between two great powers with different socio-economic systems adopted after the Second World War.

The last item, the thirteenth, which dealt with an important component of the principles of mutual cultural cooperation and development between the two countries, caused a lot of controversy between the two parties. On October 20, 1971, that is, only ten days before the declaration of the document, no compromise was reached for that item. As a result, and based on the insistence of the French side, the item stipulated that "everything that can contribute to enriching the values of mutual cooperation and developing means of improving to the Soviet and French peoples of their culture, expanding university, scientific and artistic exchanges, disseminating information and communication between organizations will be encouraged. Moreover, the French side insisted in particular on expanding contacts between citizens, including youth meetings, and trips on a group or individual basis, formal or informal.

As for the 1971 declaration, it took a new step in the German case. The two parties supported the accession of the Republic of Germany to the United Nations and affirmed that this would open new horizons for strengthening security, developing relations and expanding cooperation among all countries in Europe."

The Soviet-French documents 1970-1971 raised the significance of J. Pompidou's visits to the USSR and Brezhnev to France. These represented the highest point of cooperation between the two countries during the Pompidou presidency. They were politically important documents signed by the leaders of the two countries and indicated a favorable and friendly atmosphere for Soviet-French cooperation. This cooperation was developed by virtue of similar positions by other countries on some major problems of international politics and through good personal relations between Pompidou and Brezhnev. Although not all of the declared principles of political cooperation between the two countries were implemented, which was largely due to the emerging rapprochement between the Soviet Union and the United States of America, the bilateral documents signed in 1970-1971, especially the Protocol, objectively contributed to the easing of international tension and became clearly a "new step" in the development of Soviet-French relations. The principles of cooperation, first and foremost in its seventh item, played an important role in the development of the Final Document of the Conference on Security and Cooperation in Europe of 1975. It can be noted that the practical impact of these documents is clear in the field of economic cooperation in doubling of the capacity of trade between the Soviet Union and France between 1972 and 1974.

\section{CONCLUSION}

It can be said that Brezhnev was one of the most prominent Soviet presidents who were able to overcome all the difficulties they faced as he managed to restore his country to its earlier relations with European 
countries after the world had been divided into alliances. Despite the political and economic problems that his country faced, he was able to overcome them and cling to power for more than two decades. This allowed him to open the horizons of relations with France and the formation of committees in consultation with the French leaders. At the forefront of them is the French Prime Minister Pompidou, who visited Moscow and concluded trade agreements that had a prominent role in deepening the friendship between the two countries.

\section{REFERENCES}

\section{Arabic References}

\section{A. Theses and Dissertations}

1. Ayah Maanasri and Hajeera Rami, The Evolution of US-Soviet Relations in the Era of Leonid Brezhnev 1964-1982, Master Thesis, College of Humanities and Social Sciences, Al-Arabi Tebsi University, Tebessa, 2006.

2. Ammar Khaled Ramadan Al-Rubaie, Gorbachev and His Role in Soviet Politics until 1991, unpublished doctoral thesis, College of Education, Basra University, 2010.

B. Arabic Books

1. Ibrahim Al-Aris, Memory of the Twentieth Century May 5, 1960 Leonid Brezhnev Jumps to the Top of Power in Moscow.

2. Vladimir Tismaniano, History of Eastern Europe, translation: Amal and Rash, Egyptian General Book Authority, 1997.

3. A Group of Authors, Fire and Ice: The Red Empire: From Cradle to Grave, Dar Al-Husam Printing and Publishing, Lebanon, 1992.

\section{English References}

1. Archives du ministère des affaires étrangères. URSS. №3720.

2. Ina L. Navazelskis, Leonid Brezhnev, Chelsea House Publishers, New York, 1988, Leonid I. Brezhnev, Leonid I. Brezhnev: his Life and Work, Sphinx Press, INC, New York, 1982.

3. John Paxton, Leaders of Russia and the Soviet Union: from the Romanov dynasty to Vladimir Putin, Routledge, New York and London, 2004.

\section{Russian References}

1. Дипломатический словарь. В 3-х томах. Том 3 - М.: Политиздат, 1973 .

2. Дипломатический словарь. В 3-х томах. Том 3 - М.: Политиздат, 1973 .

3. Дубинин Ю.В. Дипломатическая быль. Записки посла во Франции. М., 1997. С.

4. Евгений Осипов, Старший научный сотрудник Института всеобщей истории РАН, кандидат исторических наук , Помпиду - Брежнев. Документы из французских архивов , Архив 4 номера 2011 года .

5. СЕРГЕ й СЕМАН0в , Брежнев от первого дня своего, ВЕ4Е, Москва, 2002 .

6. Советско-французские отношения. 1965-1976 гг. Документы и материалы.М.,1976. С.

7. Помпиду - Брежнев. Документы из французских архивов , URSS. №2679.

8. Большая советская энциклопедия, 3-е изд., Москва, Советская энциклопедия, 1971, т. 4, с. 17; Ina L. Navazelskis

9. Из учетной карты члена ВКП(б) Брежнева от 18.11 .1929 г. № 2871 , 9). время вступление в кандидаты - 9.10.1929 г. 10). На какой стаж принят - два года...». ЦДООСО. Ф. 4. Оп. 17.

10. Из автобиографии Л. И. Брежнева написанная им в 1945 г. «В 1935 году окончил институт и работал нач-ком смены в Силовом цеху на заводе им Дзержинского». РГАНИ. Ф. 80. Оп. 1. Д. 1197.

11. Лубченков Юрий Николаевич, Генеральный секретарь ЦК КПСС Леонид Ильич Брежнев 1906-1982, Moscow.

12. Л. И. Брежнев, Космический Октябрь, Главы из книги «Воспоминания , Дуэль ,2006.

13. Нападение французского самолёта на самолёт Л. И. Брежнева, ГА РФ. Ф. Р-7523. Оп. 78. Д. 


\section{Encyclopedias}

1. Abdel Wahab Al-Kayyali and others, The Political Encyclopedia, The Arab Foundation for Studies and Publishing, Dar Al-Huda, Beirut.

2. Masoud Al-Khawand, The Historical and Geographical Encyclopedia, $5^{\text {th }}$ Edition, The International Company for Encyclopedias, Beirut, 2005, Part 1.

\section{Newspapers and Magazines}

1. Al-Hayat Newspaper, Issue 12845, 1998.

2. Al-Bayan newspaper, Brezhnev, the last of the Soviet emperors, No. 490131, August 26, 2019.

\section{Websites}

1. https , arabic.rt.com, news , 24815-40 .

2. https ar.wikipedia.org. 